\title{
RELIABILITY OF A DIGITAL IMAGE METHOD FOR MEASURING MEDIAL MANDIBULAR FLEXURE IN DENTATE SUBJECTS
}

\author{
CONFIABILIDADE DE UM MÉTODO DE IMAGEM DIGITAL PARA MEDIÇÃO \\ DE DEFLEXÃO MANDIBULAR MEDIAL EM ADULTOS DENTADOS
}

Rosemary Sadami Arai SHINKAI ${ }^{1}$, Simone de Andrade CANABARRO ${ }^{2}$, Caroline Bom SCHMIDT ${ }^{3}$, Evandro Afonso SARTORI ${ }^{3}$

\begin{abstract}
1- DDS, MSc, PhD, Associate Professor, Department of Prosthodontics, Pontifical Catholic University of Rio Grande do Sul, Porto Alegre, Brazil. 2- DDS, MSc in Prosthodontics, Pontifical Catholic University of Rio Grande do Sul, Porto Alegre, Brazil.

3- Undergraduate Student, Pontifical Catholic University of Rio Grande do Sul, Porto Alegre, Brazil.
\end{abstract}

Corresponding address: Rosemary S. A. Shinkai - Avenida Cristóvão Colombo 3084, cj 708/709 - Porto Alegre, RS, Cep.: $90560-002$ - Brazil. Telefax: +55 5133203538 - Email: rshinkai@pucrs.br

Received: June 06, 2004 - Returned for modification: September 22, 2004 - Accepted: October 19, 2004

\begin{abstract}
$M$

edial mandibular flexure (MMF) is the functional approximation of hemi-mandibles in jaw opening and protrusion, which may affect conventional or implant-supported arch prostheses. OBJECTIVE: This study evaluated the intra- and inter-rater reliability of a digital image method for linear measurement of MMF in dentate subjects. MATERIAL AND METHODS: Mandibular occlusal impressions in vinyl polysiloxane during rest and maximum opening were obtained from seven adult volunteers. Each impression and the Mitutoyo digital calipers with a $10 \mathrm{~mm}$ opening were scanned at a $200 \%$ magnification. The images were processed using Adobe Photoshop software to get reference points on contralateral first molars. Linear intermolar measurements were taken using the Image Tool software (UTHSCSA), which was calibrated with the standard opening of the digital calipers. Intermolar distance was measured in triplicate for each image by two independent examiners. MMF was calculated by subtracting the intermolar distance in maximum opening (or protrusion) from the distance in rest position. Data were analyzed by intraclass correlation (ICC) tests for estimating intra- and inter-rater reliability. RESULTS: MMF values ranged from -0.21 to $0.44 \mathrm{~mm}$. Intra-rater ICCs were 0.982 and 0.993 , and inter-rater ICC was 0.696 . CONCLUSION: The present results show excellent intra-rater and good inter-rater reliability of this digital image method for measuring MMF in dentate subjects.

Uniterms: Dental arch; Jaw; Mandible; Mandibular flexure.
\end{abstract}

\footnotetext{
RESUMO

A

deflexão mandibular medial (MMF) é uma deformação funcional que ocorre com a aproximação das hemi-mandíbulas em abertura e protrusão, podendo afetar próteses convencionais e implanto-suportadas em arco. OBJETIVOS: Este trabalho avaliou a confiabilidade intra- e inter-examinador de um método de imagem digital para aferição linear da MMF. MATERIAL E MÉTODOS: Foram selecionados sete voluntários adultos dentados, obtendo-se registros oclusais inferiores de silicona de adição em repouso, abertura e protrusão máximas. Os registros foram escaneados juntamente com um paquímetro Mitutoyo com abertura de $10 \mathrm{~mm}$ num aumento de $200 \%$. A imagem foi processada no programa Adobe Photoshop obtendo-se pontos de referência intermolares, e as medições lineares foram feitas no programa ImageTool (UTHSCSA) calibrado com a medida padrão do paquímetro. Foram feitas medições em triplicata da medida da distância intermolar para cada imagem. A MMF foi calculada subtraindo-se a distância intermolar em abertura da distância em repouso/ protrusão. Os dados foram analisados por coeficientes de correlação intraclasse (ICC) para estimar a confiabilidade intra- e inter-examinadores. RESULTADOS: Os valores de MMF variaram de -0,21 a 0,44mm. Os ICCs intra-examinador foram 0,982 e 0,993, e o ICC inter-examinador foi 0,696. CONCLUSÃO: Os resultados demonstram excelente confiabilidade intra-examinador e boa confiabilidade inter-examinador deste método de imagem digital para aferição de MMF em adultos dentados.

Unitermos: Arco dentário; Mandíbula; Deflexão mandibular.
} 


\section{INTRODUCTION}

Medial mandibular flexure (MMF) is a functional elastic deformation characterized by medial convergence of hemi-

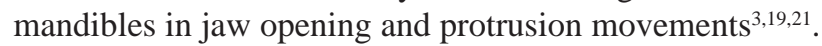
Although corporal rotation and torsion also may occur in the mandible during movement and static load ${ }^{1,11,12,16}$, MMF is the easiest functional deformation that can be measured directly in clinical studies.

MMF could lead to challenging problems with both conventional and implant-supported prostheses when treatment planning includes rigid bilateral connection in the posterior region of the mandible. Previous clinical and experimental studies reported possible association of MMF with increased stress in dental prostheses and abutments, poor fit of fixed and partial removable prostheses, impression distortion, pain during function, fracture of screws and implants, loosening of cemented prostheses, and fracture of porcelain ${ }^{6,8,9,12,13,18,20,25,26}$. One procedure suggested to overcome this problem is the division of the mandibular arch prosthesis in anterior and posterior segments or at the symphysis area, or the use of distal cantilever $6,7,8,9,17,18,26,27$. However, these procedures are not the gold standard designs for large mandibular arch prosthesis.

A large inter-subjects variability of MMF is reported and ranges from some microns to more than one millimeter ${ }^{5}$. Multiple individual factors such as muscular force, facial geometry, and bone density ${ }^{4,12,14}$ may account for these discrepancies in MMF values. Another reason for the large variability of MMF seems to be the different methods used to measure this deformation in vitro and in vivo, including transducers $^{4,13}$, video recording ${ }^{15}$, dental impressions ${ }^{10,22}$, and sophisticated computer simulations in two and threedimensions 24,26,27. Most of the methods developed for quantifying mandibular deformation are difficult to perform or require expensive equipment since they were not designed for clinical application. A fast, easy, inexpensive, and reliable method to measure MMF and detect subjects potentially at risk for problems derived from this type of deformation would be helpful to practitioners.

Therefore, the purpose of this paper was to present a digital image method for linear measurement of MMF in dentate subjects and to evaluate its inter- and intra-rater reliability (absolute agreement).

\section{MATERIALAND METHODS}

Seven adult subjects were randomly drawn from a sample of 87 volunteers recruited from the students and faculty of the Dental School of the Pontifical Catholic University of Rio Grande do Sul. Eligibility criteria included complete dentition (facultative presence of third molars), age range from 20 to 50 years old, and normal occlusion. Subjects were excluded if they had history of maxillofacial surgery, mandibular trauma or orthodontic treatment within the previous two years; presence of active periodontal disease with tooth mobility, osseous or neuromuscular diseases, large facial skeletal alterations, or orofacial pain; or if they were pregnant. This sample was selected for a study project of a multivariate model for mandibular flexure, which was approved by the University's Institutional Review Board according to national and international standards for clinical research.

\section{Dental impressions}

For each subject, impressions of the occlusal and incisal thirds of the mandibular teeth were obtained during relative rest (minimum mouth opening only for impression making), maximum opening, and maximum protrusion. A customized metallic support similar to a bite fork of a semi-adjustable articulator was used as a tray for the vinyl polysiloxane putty material (3M Express, Saint Paul, MN, USA). Impressions were standardized with centric stops on bilateral canines and molars that were in contact with the metallic support.

\section{Digitalization of the dental impressions and image processing}

The impressions and the Mitutoyo digital calipers (Mitutoyo Sul Americana Ltda, Suzano, São Paulo, Brazil) with a $10 \mathrm{~mm}$ opening were scanned at a $200 \%$ magnification and 300dpi resolution by using a desk scanner HP ScanJet 6100 C/T (Hewlett Packard Co., Colorado, USA) and the software Deskscan (Hewlett Packard Co., Colorado, USA). Positioning of the impression during digitalization was standardized by using a support that kept the metallic tray and the impression plane parallel to the scanner surface. The digitized images were saved in Joint Photographic Experts Group (JPEG) format and processed by Adobe Photoshop ${ }^{\circledR} 4.0$ software.

Using the Adobe Photoshop tools, each image was changed to greyscale, inverted, and adjusted for brightness and contrast to reach the best visualization of the occlusal surface (Figure 1). At a 200\% zoom, anatomical reference points on the contralateral first molars were chosen for the three images (R, O, P) and marked with a 5-pixel red point. All processed images were saved in JPEG format. All three images for each subject ( $\mathrm{R}=$ rest, $\mathrm{O}=$ opening, $\mathrm{P}=$ protrusion) were processed simultaneously on the computer monitor.

\section{Measurement of the intermolar distance and calculation of MMF}

All linear measurements were performed using the Image Tool software (University of Texas Health Science Center at San Antonio, San Antonio, TX, USA; this software can be downloaded at http://ddsdx.uthscsa.edu) at a 2:1 magnification. Each image measurement was calibrated with the standard opening of the digital calipers $(10 \mathrm{~mm})$ with the tool "settings - calibrate spatial measurements".

Linear measurement between the two reference points on the contralateral first molars was done by tracing a line between the outer borders of the reference points. The 
software calculated the intermolar distance in millimeters according to the previous calibration (Figure 2). Accuracy of the linear measurement was $0.01 \mathrm{~mm}$. Two independent examiners (S.A.C. and C.B.S.) performed the measurements in triplicate for each image. MMF was calculated by subtracting the intermolar distance in maximum opening (or maximum protrusion) from the intermolar distance in rest position.

\section{Statistical analysis}

Data were analyzed by the SSPS Plus for Windows 11.5 software. Intra- and inter-rater reliabilities were estimated by using intraclass correlation (ICC) tests ${ }^{2,23}$ under a two-way mixed effects model with measures of absolute agreement. Intra-rater ICCs were calculated for each examiner considering their three measurement values for each subject. Inter-rater ICC was estimated by using the average measurement value of each subject (mean of the three measurements) per examiner.

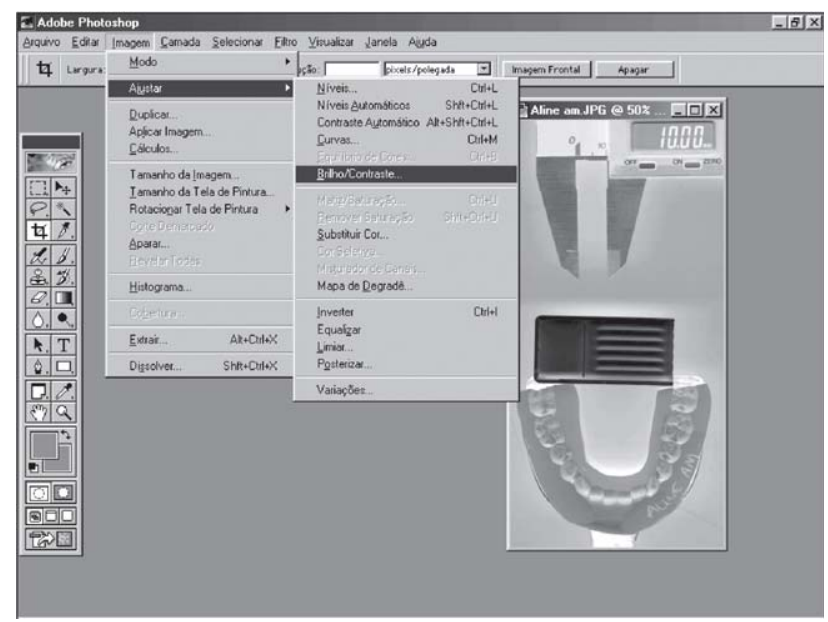

FIGURE 1- Image processing in the Adobe Photoshop ${ }^{\circledR}$ 4.0 software: Inversion, grey scale, and adjustment of contrast and brightness

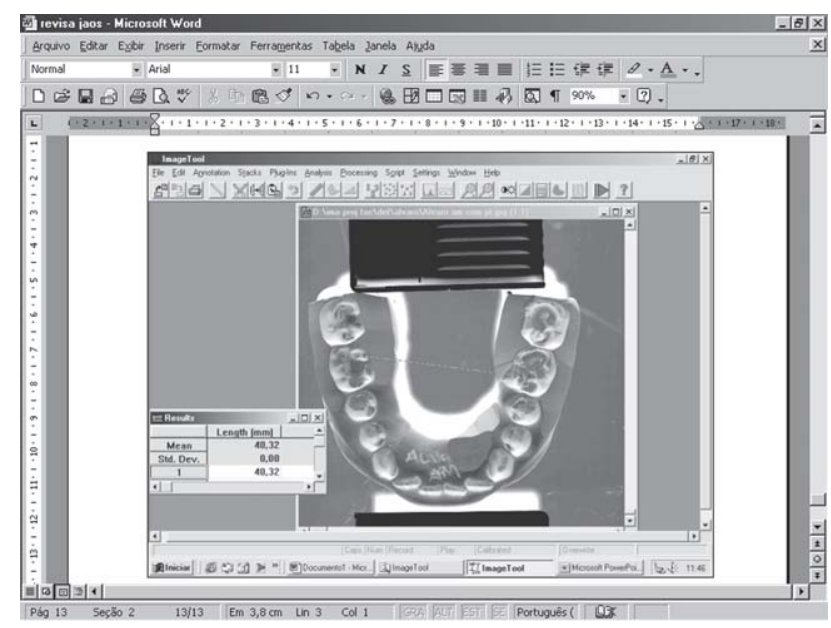

FIGURE 2- Measurement of the intermolar distance in the ImageTool ${ }^{\circledR}$ software

\section{RESULTS}

Table 1 displays the original readings of the two independent examiners. Range of MMF measures within each subject varied from -0.21 to $0.44 \mathrm{~mm}$. Considering the triplicate measurements of both examiners combined, for each subject, MMF values ranged from 0 to $0.36 \mathrm{~mm}$.

Intra-rater ICCs were 0.982 and 0.993 for examiners 1 and 2 , respectively. Inter-rater ICC was 0.696.

\section{DISCUSSION}

Although many procedures to measure MMF in humans have been reported, no gold standard is available as all methods have advantages and disadvantages. Other studies used transducers fixed onto dental surfaces ${ }^{4}$ or implants ${ }^{13}$, customized calipers ${ }^{18}$, and impressions of the mandibular teeth $^{10,22}$. Digital images of occlusal mandibular impressions were used to measure the intermolar distance and calculate MMF. Scanning the impressions to obtain digital images may minimize distortions that could be incorporated by direct video recording the mandibular positions ${ }^{15}$ or by photographs of the teeth ${ }^{7}$. However, special attention is required to standardize the positioning of the impressions during scanning to prevent image distortion.

The accuracy of the impression method also should be considered as function of the chosen impression material. Similar studies in the literature used alginate and stone models ${ }^{10}$ or condensation silicon ${ }^{22}$. Vinyl polysiloxane putty material was selected for this study because presents good reproduction of details and higher dimensional stability than the other available impression materials. In addition, the software used for the linear measurements (ImageTool ${ }^{\mathrm{TM}}$ ) presents sensitivity of $0.01 \mathrm{~mm}$, which is a reasonable cutoff for clinical purposes.

Intra- and inter-examiner agreement estimates were calculated by intra-class correlation coefficients (ICCs). ICC may be conceptualized as the ratio of between-groups variance to total variance. Inter-rater reliability measures homogeneity so as to establish the extent of consensus on use of the instrument by those who administer it. ICC is recommended to assess test-retest reliability with small sample size $(<15)$ or when more than two tests will be correlated $^{2,23}$.

Both examiners (an experienced graduate in Prosthodontics and a junior dental student) achieved similar high levels of intra-rater agreement. This indicates that level of dental training and professional experience does not affect intra-rater repeatability of measurements with this method. Inter-rater reliability was not as high as intra-rater reliability though. Critical steps within this method are the placement of the reference points on the images and the intermolar distance measurement. Differences in these procedures may account for the variability of measures between examiners seen in this study.

Limitations of this method include the impossibility of assessment in individuals with no reference anatomical 
points in the mandible, e.g., large edentulous areas in the posterior region of the mandible or totally edentulous subjects with no implants. Also, a minimum level of training with both the graphic and measuring softwares is required.

The magnitude of MMF with clinical significance still is unknown ${ }^{5}$. Perhaps the definition of an exact number as a cut-off point would not be possible as multiple factors are involved in MMF, and subjects may compensate for this phenomenon differently. However, when facing a clinical problem involving mandibular arch prosthesis, measurement of MMF may provide support to change treatment plan and prosthesis design, or rule out flexure-related issues. At present, other studies in our lab within this same project are looking at muscular and bone factors involved in the MMF and may help elucidate how to diagnose patients potentially at risk for extensive oral rehabilitation in the mandible. The final aim is to develop an easy and viable clinical method for measuring MMF in the daily practice.

\section{CONCLUSIONS}

The results showed excellent intra-rater and good interrater reliability of this digital image method for measuring MMF in dentate subjects. This is a simple method and may be useful to identify subjects with excessive MMF.

\section{ACKNOWLEDGEMENTS}

This project was partially supported by CAPES (scholarship), CNPq (scholarship), and FAPERGS (grant), Brazil.

\section{REFERENCES}

1- Abdel-Latif HH, Hobkirk JA, Kelleway JP. Functional mandibular deformation in edentulous subjects treated with dental implants. Int J Prosthodont 2000;13:513-9.

2- Bravo G, Potvin L. Estimating the reliability of continuous measures with Cronbach's alpha or the intraclass correlation coefficient: towards the integration of two traditions. J Clin Epidemiol 1991;44:381-90.

3- Burch JG. Patterns of change in human mandibular arch width during jaw excursions. Arch Oral Biol 1972;17:623-31.

4- Chen DC, Lai YL, Chi LY, Lee SY. Contributing factors of mandibular deformation during mouth opening. J Dent 2000;28:583-8.

5- Cumerlato ML, Giustina, JD, Canabarro SA, Shinkai RS. Deflexão mandibular medial: Implicações protéticas. Rev. Odonto Ciência 2003;18:171-8.

6- De Oliveira RM, Emtiaz S. Mandibular flexure and dental implants: a case report. Implant Dent 2000;9:90-95.

7- Fischman B. The rotational aspect of mandibular flexure. J Prosthet Dent 1990;64:483-5.

TABLE 1- Raw data of MMF (in millimeter) in maximum opening (MMF-O) and protrusion (MMF-P)

\begin{tabular}{|c|c|c|c|c|c|c|}
\hline & \multicolumn{3}{|c|}{ Examiner 1 (S.A.C.) } & \multicolumn{3}{|c|}{ Examiner 2 (C.B.S.) } \\
\hline & Time 1 & Time 2 & Time 3 & Time 1 & Time 2 & Time 3 \\
\hline \multicolumn{7}{|l|}{ MMF-O } \\
\hline Subject 1 & 0.44 & 0.44 & 0.44 & 0.44 & 0.44 & 0.43 \\
\hline Subject 2 & 0.09 & 0.1 & 0.1 & 0.08 & 0.1 & 0.09 \\
\hline Subject 3 & 0.36 & 0.36 & 0.36 & 0.3 & 0.31 & 0.31 \\
\hline Subject 4 & -0.07 & -0.09 & -0.09 & 0.27 & 0.24 & 0.24 \\
\hline Subject 5 & -0.1 & -0.1 & -0.1 & -0.1 & -0.09 & -0.1 \\
\hline Subject 6 & 0.36 & 0.36 & 0.36 & 0.19 & 0.19 & 0.19 \\
\hline Subject 7 & 0.05 & 0.05 & -0.13 & 0.05 & -0.13 & 0.05 \\
\hline \multicolumn{7}{|l|}{ MMF-P } \\
\hline Subject 1 & 0.02 & 0.04 & 0.02 & 0.04 & 0.05 & 0.03 \\
\hline Subject 2 & 0.15 & 0.15 & 0.15 & -0.21 & -0.2 & -0.21 \\
\hline Subject 3 & 0.2 & 0.21 & 0.2 & 0.18 & 0.2 & 0.18 \\
\hline Subject 4 & 0.07 & 0.07 & 0.07 & 0.44 & 0.42 & 0.43 \\
\hline Subject 5 & 0.02 & 0.01 & 0.02 & 0.02 & 0.02 & 0.02 \\
\hline Subject 6 & 0.18 & 0.18 & 0.22 & 0.19 & 0.19 & 0.19 \\
\hline Subject 7 & 0.22 & 0.22 & 0.22 & 0.22 & 0.22 & 0.22 \\
\hline
\end{tabular}


8- Fischman BM. The influence of fixed splints on mandibular flexure. J Prosthet Dent 1976;35:643-7.

9- Gates G, Nicholls JI. Evaluation of mandibular arch width change. J Prosthet Dent 1981;46:385-92.

10- Goodkind RJ, Heringlake CB. Mandibular flexure in opening and closing movements. J Prosthet Dent 1973;30:134-8.

11- Hobkirk JA, Havthoulas TK. The influence of mandibular deformation, implant numbers, and loading position on detected forces in abutments supporting fixed implant superstructures. J Prosthet Dent 1998;80:169-74.

12- Hobkirk JA, Schwab J. Mandibular deformation in subjects with osseointegrated implants. Int J Oral Maxillofac Impl 1991;6:319-28.

13- Horiuchi M, Ichikawa T, Noda M, Matsumoto N. Use of interimplant displacement to measure mandibular distortion during jaw movements in humans. Arch Oral Biol 1997;42:185-8.

14- Hylander WL. Stress and strain in the mandibular symphysis of primates: A test of competing hypotheses. Am J Phys Anthropol 1984;64:1-46.

15- Jiang T, Ai M. In vivo mandibular elastic deformation during clenching on pivots. J Oral Rehabil 2002;29:201-8.

16- Korioth TW, Hannam AG. Deformation of the human mandible during simulated tooth clenching. J Dent Res 1994;73:56-66.

17- McCartney JW. Cantilever rests: an alternative to the unsupported distal cantilever of osseointegrated implant-supported prostheses for the edentulous mandible. J Prosthet Dent 1992;68:817-9.

18- Omar R, Wise MD. Mandibular flexure associated with muscle force applied in the retruded axis position. J Oral Rehabil 1981;8:20921

19- Osborne J, Tomlim HR. Medial convergence of the mandible. Br Dent J 1964;117:112-4

20- Paez CY, Barco T, Roushdy S, Andres C. Splint-frame implant prosthesis designed to compensate for mandibular flexure: a clinical report. J Prosthet Dent 2003;89:341-3.

21- Regli CP, Kelly EK. The phenomenon of decreased mandibular arch width in opening movements. J Prosthet Dent 1967;17:49-53.

22- Sesma N, Ribeiro FC, Zanetti AL. Deflexão mandibular e suas relações com próteses e implantes osseointegrados. Rev Assoc Paul Cir Dent 1996;50:73-7.

23- Shrout PE, Fleiss Jl. Intraclass correlations: Uses in assessing rater reliability. Psychological Bull 1979;86:420-8.

24- Vollmer D, Meyer U, Joos U, Vegh A, Piffko J. Experimental and finite element study of a human mandible. J Craniomaxillofac Surg 2000;28:91-6.

25- Yamashita J, Shiozawa I, Takakuda KA. A comparison of in vivo and in vitro strain with posterior fixed partial dentures. J Prosthet Dent 1997; 77:250-5

26- Yang HS, Lang LA, Felton DA. Finite element stress analysis on the effect of splinting in fixed partial dentures. J Prosthet Dent 1999;81:721-8.

27- Zarone F, Apicella A, Nicolais L, Aversa R, Sorrentino R. Mandibular flexure and stress build-up in mandibular full -arch fixed prostheses supported by osseointegrated implants. Clin Oral Impl Res 2003;14:10314. 